\title{
The Judicial Control over the Constitutionality of Laws in the State of Palestine
}

\author{
Ahmed M A Hamad ${ }^{1 *}$; Emad Mohammad Al Amaren ${ }^{2}$; Omar Farouk Al \\ Mashhour ${ }^{3}$; Kukuh Tejomurti ${ }^{4}$; Haslinda binti Mohd. Anuar ${ }^{5}$; Rohizan binti. \\ Halim $^{6}$
}

\begin{abstract}
1,2,3,5,6 School of Law, Universiti Utara Malaysia, Sintok, Kedah, 06010, Malaysia,
${ }^{4}$ Faculty of Law, Universitas Sebelas Maret, Surakarta, East Java, 57126, Indonesia

*Corresponding author: ahmadh1992@hotmail.com
\end{abstract}

\begin{tabular}{|c|c|}
\hline Article & Abstr \\
\hline $\begin{array}{l}\text { Article History } \\
\text { Received: July 14, 2020; } \\
\text { Reviewed: July 28, 2020; } \\
\text { Accepted: Sept 09, 2020; } \\
\text { Published: Sept 30, } 2020\end{array}$ & $\begin{array}{l}\text { This article aimed to explore the judicial control over the constitutionality of laws } \\
\text { in the State of Palestine. The article problem was represented in the authority } \\
\text { involved with judicial control over the constitutionality of laws in Palestine, and } \\
\text { what is the legal effect of ruling on the unconstitutionality of specific legislation? } \\
\text { The judicial control is meant the constitutional judiciary undertakes to examine } \\
\text { the constitutionality of laws and regulations issued by the Legislative Council or } \\
\text { the President of State, to determine whether they are in conformity with the } \\
\text { constitution or are in violation of it. This article uses normative legal research with } \\
\text { using legislation approach and doctrinal approach. The importance of this article } \\
\text { is that it has been discussed the legal framework governing judicial control of the } \\
\text { constitutionality of laws in Palestine, and sheds light on the concept of judicial } \\
\text { control, its mechanisms, nature, and effects to ensure the protection and } \\
\text { consolidation of constitutional texts..In order to achieve the objective of this study, } \\
\text { the socio-legal research using the qualitative approach was engaged to describe and } \\
\text { analyse the opinions of jurists, legal texts, and rulings of constitutional courts in } \\
\text { Palestine. Among the most important results that the author reached is that the } \\
\text { state of law cannot be established without adopting the principle of judicial control } \\
\text { over the constitutionality of laws to protect the legal texts that exist within the } \\
\text { constitution, which is the supreme law within the legislative hierarchy. }\end{array}$ \\
\hline \multicolumn{2}{|c|}{$\begin{array}{l}\text { (C)2020; This is an Open Acces Research distributed under the term of the Creative Commons } \\
\text { Attribution Licencee (https://Creativecommons.org/licences/by/4.0), which permits unrestricted } \\
\text { use, distribution, and reproduction in any medium, provided the original works is properly cited. }\end{array}$} \\
\hline
\end{tabular}




\section{INTRODUCTION}

The Palestinian Basic Law of 2003 is one of the laws that provide for judicial control over the constitutionality of laws (Text of Article (103) of The Palestinian Basic Law, 2003). The state of law adopts the principle of the supremacy of the constitution or the basic law as some countries call it, according to which, the constitutional rules are granted the highest rank in the hierarchy of the internal legal system, and the consequent respect for the lower legal rules for higher legal rules (A. M. A. Hamad, Anuar, \& Halim, 2020). In addition, the state of law establishes guarantees to protect constitutional texts through judicial control over the constitutionality of laws in order to verify legislation if they violate the constitution or not (Badir, 2017). Moreover, judicial control over the constitutionality of laws is the most effective way to ensure respect for the constitution and its supremacy over other legal rules within the country. Furthermore, this control could be political when it is assumed by a political body, and it could be judicial when it is entrusted to a body of judicial nature (Al-Abdullah, 2001).

The judicial control also could be a precedent for the issue of the law, and it could be subsequent to its issuance (Noman Ahmad Al-Khatib, 2011: 5). In addition, the judicial control over the constitutionality of laws aims to achieve a state of law based on the principle of supremacy of the constitution or the Basic Law (El-Lamsaoui, 2009). Also, Judicial oversight over the constitutionality of laws is one of the basic and important guarantees for the correct implementation of the constitution. This oversight ensures the realization of the principle of legality and legitimacy in complementarity with the principle of the supremacy of the constitution and the hierarchy of legislation within the state.

Additionally, Judicial oversight of the constitutionality of laws is, in fact, a method used by democratic countries to compel both the laws and executive authorities to respect the constitution in their actions or decisions and the laws they enact, which guarantees full constitutional protection of the rights and freedoms of individuals within the state.

However, the control of the constitutionality of laws does not arise except in the light of rigid constitutions, in contrast to flexible constitutions. Amending them requires strict procedures that differ from the procedures for amending ordinary legislation because these constitutional rules enjoy a high position. While flexible constitutions are amended by the procedures and principles followed in amending the regular legislation.

The Palestinian Basic Law of 2003 and the Jordanian Constitutional Law of 1952 consider both of them to be rigid constitutions. Judicial oversight over the 
constitutionality of laws is embodied in both of them. Neither of them can be amended except according to special procedures that differ from the procedures used to amend ordinary laws.

It should be noted here that the Palestinian legislator has adopted oversight through the original direct lawsuit, in a step ahead of what the Egyptian legislator has taken, which is limited to the constitutional control movement on methods of referral, and sup objection. Whereas, this method allows every aggrieved person to resort to the Supreme Constitutional Court directly to file his appeal against the unconstitutionality of the law because it affects his interest through an original lawsuit directly before it (Al-Tahrawi, 2007).

The importance of this article that it will discuss the legal framework regulating judicial control over the constitutionality of laws in Palestine, also, highlighting what is meant by judicial control over the constitutionality of laws and comparing them to political oversight, and then methods of judicial control over the constitutionality of laws.

\section{METHOD}

The research method used in this study is a normative research method (Stutz \& Sachs, 2016). Library studies are conducted to obtain secondary data in the form of primary legal materials (legislation), and secondary legal materials (doctrines). To answer questions in the formulation of the problem, a regulatory and doctrinal approach is used. The data presented is qualitative, and is presented with a descriptive method of analytics.

\section{RESULTS AND DISCUSSION}

Judicial Control over the Constitutionality of Laws and Comparison with Political Oversight.

Judicial control over the constitutionality of laws is the second method of control (El-Ghali, 2009). It is meant that the judiciary could examine the constitutionality of laws or regulations issued by parliament or the president of the state, to determine whether they are in conformity with the constitution or violate it, and in this way, this control is distinguished from its political counterpart in that those assumed by the judiciary rather than politicians, as it is assigned to courts, not for political bodies (Abdel-Wahab, 2001).

In addition, some jurists call this control a "Judicial solution to the constitutionality of laws" (El-Ghali, 2009). There are also some jurists who emphasize that judicial control is better than political oversight (El-Sharkawi, 2010) and it achieves advantages that are not found in the latter (Abdullah, 1997) the most important of 
which are the following: Judicial control is consistent with the essence and basis of the problem of constitutional oversight, as this problem is legal rather than political, to be raised regarding the extent to which the laws conform to the constitution or not, and therefore this task must be assumed by judges, with their experience in enforcing the rules of the law and applying and interpreting it (Abdel-Wahab, 2001). In addition, the judiciary is characterized by its independence and impartiality, which is well reflected in the oversight process and its best functioning, unlike political oversight that is subject to governmental or parliamentary whims and interests, according to the method chosen by the government or parliament (Abdullah, 1997).

Furthermore, the judicial control is distinguished by its being subject to fair judicial principles and procedures, which enhance confidence and trust in its proper functioning, such as the principles of openness, freedom of defence, and causing of sentences (Abdel-Wahab, 2001). Moreover, the judicial control over the work of Parliament, which represents the nation, does not contradict the principle of the sovereignty of the nation, because the constitution shall be protected from the deviation of Parliament, also the constitution is considered the supreme document that essentially reflects the will of the nation (Al-Bahri, 2006).

In Palestine, the birth of judicial control over the constitutionality of laws was not an easy matter, just as the real existence of this control emerged with the return of the Palestinian National Authority from its exile to the homeland of Palestine and the issuance of the Basic Law, not before that. In the previous stages of the return of the Palestinian National Authority, and while Palestine is subject to the rule of successive foreign administrations, the basic constitutions and laws issued by these administrations have lacked reference to this control (Al-Tahrawi, 2007). After the return of the Palestinian National Authority and the issuance of the Basic Law of 2003, a tangible development was achieved within the framework of judicial control over the constitutionality of laws in Palestine. Since for the first time the text explicitly came to the right of the judiciary to extend its control over the constitutionality of laws, and accordingly, the Constitutional Court was formed to take over this task (Al-Tahrawi, 2007) and until this formation is completed, the Supreme Court will temporarily assume this task (Article (103) of the Palestinian Basic Law of 2003).

Based on the foregoing, the Supreme Court assumed the task of control over the constitutionality of laws until the formation of the Constitutional Court and affirmed that it has the power to control over the constitutionality of laws (Ma'rifatulloh, 2019) and regulations in absolute terms, including laws established by the Legislative Council, and decisions issued by the President of the state (A. M. Hamad, 2019). Therefore, this is affirming on the principle of the supremacy of the 
Basic Law, in a manner that leads to the realization of the height of its rules over all other legal rules, whether statutory or regulations, so that the latter may not violate the legal rules contained in the Basic Law, in order to ensure apply the principle of legality and to prevent the public authorities from violating the constitutional restrictions and the limits of their powers ("The Ruling of the Supreme Court in Its Constitutional Capacity That Was Held in Ramallah in the Constitutional Case No. 3 of 2009," 2010).

\section{Judicial Control Methods over the Constitutionality of Laws}

Although most countries have tended to adopt judicial control over the constitutionality of laws, yet they have not agreed to adopt a single method to achieve this control, some of them adopt this control through the original lawsuit, and others adopt the control through the sub-objection (Abdullah, 1997). As follows, the control through the original lawsuit, then the control through sub-objection.

\section{The Control Through the Original Lawsuit}

This control means that the person affected by a specific law may appeal against it before the competent court for violating the provisions of the constitution, and even before this law is applied to him (Al-Khatib, 2011). In the event that it is already proven that this law is contrary to the provisions of the constitution, the court shall order its abolition for its unconstitutionality, and consider it as if it was not, and it's ruling of the abolition applies to all and is an argument for everyone. But in the event that the law is constitutional, it requires the dismissal of the case, and the law remains in effect.

In addition, the Palestinian Supreme Court, authorized temporarily to consider constitutional appeals (Article No. (104) of the Palestinian Basic Law of 2003), indicated that the original lawsuit represents the way it relates to the constitutional dispute and that this lawsuit aims to cancel the legal action that is contested as unconstitutional, such a lawsuit is initiated by the person affected by the application of the law or order, in confirmation of the fulfilment of a condition interest in relation to this lawsuit ("The Ruling of the Supreme Court in Its Constitutional Capacity Held in Ramallah in Constitutional Law No. 1 of 2010," 2010).

turn, the Supreme Court of Justice, in its capacity as a court of cancellation ("The Ruling of the Supreme Court in Its Constitutional Capacity Held in Ramallah in Constitutional Law No. 640 of 2010," 2012), during its consideration of the case before it to cancel the decision of the Public Prosecutor to refer the appellant to the military judiciary, indicated that the constitutional provisions have their absolute authority, and therefore they are binding on all without exception, and all institutions, bodies, and individuals are bound by them. Therefore, violation of the decision of the Attorney General for the ruling of the Constitutional Court issued earlier, and his referral of the 
appellant to the military judiciary, even though he is a civilian and not for the regular courts, with which the decision becomes no value (Abdullah, 1997). In addition to the laws, the court may impose its control by way of the original lawsuit or cancel of the drafts that have not been approved yet, which makes judicial control by the original lawsuit similar to political oversight in some cases, whereby this control is applied to the drafts before they are issued, however, it is common with regard to judicial control, it moves after the issuance of the law, not in most cases before that.

The Supreme Court indicated that the constitutional lawsuit is filed only by the person concerned, and whoever has an interest in establishing it and will not accept those who do not have this interest as an essential condition for the validity of filing this lawsuit. In addition to that, the interest must continue and remain until the judgment is issued in the constitutional lawsuit so that if this interest is negated while the case is being heard, it means losing the case on the basis on which it was based (ElSharkawi, 2010).

In addition, the judicial control is distinguished by the original lawsuit, as it moves through an initial lawsuit, which the person concerned submits and directs it independently and directly against a specific law, which makes this case an objective and not a personal case, because the litigation in it does not relate to extending judicial protection to personal rights for the appellant, a specific person is not contested, rather it is used primarily to repeal a law that the appellant considers unconstitutional, and requires the judiciary to issue a ruling to repeal it.

In turn, the Supreme Court referred to the substantive nature of the constitutional lawsuit, by stating in one of its rulings that this lawsuit is aimed at challenging the laws and regulations that are applied within the state, so the essence of the constitutional dispute is based on challenging the unconstitutionality of these laws and regulations when applied to persons (Metwally, 1999). The abolition ruling issued in this lawsuit is distinguished by that it is decisive for the final and one-time dispute over the constitutionality of the law. The abolition of the law that violates the constitution results in its removal and the non-continuation of its application, which means that it is not possible to return again to challenge the unconstitutionality as it no longer exists and that the ruling issued with the cancellation, its argument is absolute (El-Sharkawi, 2010).Moreover, the countries differ among themselves regarding the determination of the judicial authority that has the power to control the constitutionality of laws by way of the original case, as some of them assign this task to all courts in the state, which is known as the decentralization of control, while others assign this task to a specific court and not others, and this is known as the centralization control method (Metwally, 1999). 
It is worth noting that, the jurisdiction of the Supreme Court in Palestine with constitutional appeals is a central jurisdiction and this indicates that Palestine takes central control over the constitutionality of laws, by entrusting one court with this control, which is the highest court in the hierarchy for the ordinary judiciary. This results in the inadmissibility of consideration of these appeals by other courts. On this basis, the High Court of Justice ruled that it did not have the right to consider constitutional appeals for not having jurisdiction over these appeals, and then the appellant must resort to the competent court and not to the Supreme Court of Justice.

The Supreme Court has indicated in several rulings issued by it that it applies the rules of the Constitutional Court Law to the constitutional cases pending before it as long as this court has not been formed, and from this law, it derives its authority to control the constitutionality of laws, and it monitors the progress of the constitutional lawsuit in accordance with the procedures organized by its rules. In addition, with the issuance of the Palestinian Basic Law of 2003, the features of the judicial oversight of the constitutionality of laws became clear, as this law adopted a centralized method of control, and stipulated the establishment of the Constitutional Court to take charge of constitutional appeals, but that until the formation of this court, the Supreme Court temporarily handles this task (Article (103) (104) of Palestinian the Basic Law of 2003), which reveals the future trend of the Palestinian legislator to introduce the system of the specialized court. Moreover, the fact in 2006 (Article (1) of The Supreme Constitutional Court Law, 2006), the Constitutional Court Law was issued (Article (24) of the Constitutional Court Law No. (3) of 2006). However, this court was not formed immediately, so the Supreme Court remained competent to consider constitutional appeals while applying the provisions of this law to the cases before it, and according to this law, the Supreme Court has got the powers granted to the Constitutional Court, including controlling the constitutionality of laws and regulations, interpretation of constitutional and regular statutory texts related to the work and relationships of public authorities, adjudication of conflict of jurisdiction between judicial and administrative authorities with jurisdiction, adjudication of conflict-related to the implementation of two contradictory final judicial rulings, and adjudication of the challenge of losing the President of the state to legal capacity (Article (103) of the Palestinian Basic Law of 2003).

In April 2016, Palestinian President Mahmoud Abbas issued a presidential decree to form the Constitutional Court in accordance with its Law No. 3 of 2006, and according to Article No. (103) of the Basic Law of 2003, which means stopping the Supreme Court's authority to accept cases constitutionalism from this date, and that all lawsuits filed after this date will be within the jurisdiction of the Constitutional 
Court and not the jurisdiction of the Supreme Court (Article (104) of the Palestinian Basic Law of 2003).

\section{Control Through Sub-Objection}

Judicial control over the constitutionality of laws is achieved by sub-objection (Al-Abdullah, 2001), when the judge refuses to apply the unconstitutional law (Abdullah, 1997). It means the court refraining from applying the law that violates the constitution based on an objection made by the stakeholder or by the initiative from the court, in a case before it, based on respecting the law of the lowest to the highest, according to the principle of gradual law (Al-Khatib, 2011). Or it is the method that gives the person concerned who will be subjected to a law that violates the constitution in a lawsuit to which he is a party, by objecting to the invalidity of this law, and then the court stops the settlement of this lawsuit until the issuing a ruling from the Constitutional Court or the Supreme Court about the extent of the constitutionality of this law, after that, the ordinary court issues its ruling accordingly.

Based on the foregoing, control by sub-objection always require the existence of a lawsuit before a certain court, whatever the nature of the lawsuit, civil, commercial, criminal, or administrative, and then one of its parties argues that the law that would apply to the dispute is unconstitutional. and this control is for all courts in the judicial system of various degrees and types (Shitor, 2020) As such, it is a subsequent control over the issuance of the law (Al-Abdullah, 2001). Therefore, this control is for all courts in the judicial system of various degrees and types (Abdullah, 1997).

If the control through the original case is considered offensive control, the control by sub-objection is considered defensive with multiple results. The aim of which is not only to abolish the law that violates the constitution but also not to apply it to the dispute before the court (Al-Khatib, 2011). In addition, there is no doubt that this control does not need a constitutional text confirming its existence, and the judge's enjoyment of it, on the basis that the judge's position regarding objection to apply a law that violates the constitution stems from the core of his work and his job, and represents a duty he has no choice or hesitation in.

However, the authority of the judge here is limited only to objecting to applying of the violating law only without his ruling that it is unconstitutional. Because the judge is not competent to do so, as the judge is required to wait until the ruling on the constitutionality of the law is issued by the relevant court (Al-Hanayneh, 2013). In addition, the United States is the basis and cradle of this control (Abdullah, 1997). 
Regarding the applications of this type of control in Palestine, it can be said that the judicial rulings issued by the various courts, including the Supreme Court, indicate the prevalence of the method of control by way of the original case at the expense of control by way of sub objection, although there is no objection to resorting to this last method. The Supreme Court has repeatedly indicated that the constitutional lawsuit relates to its case through an original lawsuit filed in front of it to demand the abolition of the contested law, so that the person affected by the application of the law raises an original lawsuit before it to demand its cancellation, in light of the existence of an existing and continuing interest for him in this lawsuit.

In addition, to control through the original case and sub-objection, there is a third way to move the constitutional case, and judicial control over the constitutionality of laws, and has its applications in the Palestinian judicial system, which is known as referral to the Constitutional Court through the trial court ("The Ruling Supreme Court in Its Constitutional Capacity Held in Ramallah in Constitutional Law No. 2 of 2011," 2011).

After the promulgation of the Constitutional Court Law of 2006, a noticeable development was achieved in terms of procedures and methods for judicial control of the constitutionality over laws in Palestine, where this control has been made through several methods clearly and explicitly stated in the law, contrary to what was the case before, as mentioned above. Therefore, these methods are as follows: 1 . The original direct lawsuit filed by the person affected by law enforcement. 2. Sub-objection to litigants during the hearing of a case before a court or bodies with jurisdiction that unconstitutionally stipulates a provision in a law, decree, regulation, or decision, where the court here verifies the seriousness of the objection, and then defers consideration in the lawsuit until the ruling is issued by the Constitutional Court concerning the constitutionality of the law, order, or decision. 3. Referral to the Constitutional Court by the trial court or bodies with jurisdiction if it deems the law, order or decision unconstitutional during its consideration of the dispute before it. 4. The Constitutional Court itself, on its own initiative, addresses any law or text that finds it unconstitutional, while examining the cases brought before it (Article (27) of the Constitutional Court Law of 2006).

\section{CONCLUSION}

The rule of law cannot be established without the state adopting the principle of judicial control over the constitutionality of laws in order to protect constitutional texts that occupy the highest rank within the legislative hierarchy. Accordingly, lower-level rules must respect the higher-level rules. The difference of states in regulating the issue of judicial control over the constitutionality of laws. Some countries adopt central 
control over the constitutionality of laws, while others adopt decentralization control. There are a variety of methods for contacting the Constitutional Court with the constitutional lawsuit. There is the original lawsuit method, sub-objection, referral, or response.

While the recommendations of this article include activating the role of the Supreme Constitutional Court in control over the constitutionality of laws in Palestine, especially with the increase in cases of violations of the provisions of the Palestinian Basic Law of 2003. The selection of members of the Supreme Constitutional Court from the competencies and without taking into consideration the political affiliation of any party, as they are supposed not to belong to any party.

\section{References}

Abdel-Wahab, M. (2001). Constitutional Law and General Constitutional Principles. Alexandria, Cairo: Al-Maaref Institution.

Abdullah, A. al-G. B. (1997). Political Systems and Constitutional Law. Cairo: Arab Renaissance House.

Al-Abdullah, O. (2001). Monitoring of the Constitutionality of Laws, A Comparative Study. Journal of Damascus University, 17(2), 3. https://doi.org/10.1007/978-3319-55186-9_1

Al-Bahri, H. M. (2006). Mutual Control between the Legislative and Executive Authority as a Guarantee of Enforcement of Constitutional Rules. Ain Shams University.

Al-Hanayneh, O. A. (2013). The Right of the Regular Judiciary to Control the Constitutionality of Laws, United States of America as a Model. Journal of Sharia and Law Studies, University of Jordan, 40(1), 260.

Al-Khatib, N. A. (2011). Mediator in Political Systems and Constitutional Law (Seventh Ed). Amman, Jordan: Dar Al Thaqafa for Publishing and Distribution.

Al-Tahrawi, I. A.-Q. (2007). Control of the Constitutionality of Laws in Egyptian and Palestinian Law. Institute of Arab Research and Studies.

Badir, N. (2017). Judicial control over the Constitutionality of Laws. Birzeit, Palestine: Birzeit University, Palestine: Birzeit Working Paper Series for Legal Studies.

El-Ghali, K. (2009). Principles of Constitutional Law and Political Systems. Damascus: Military Housing Press.

El-Lamsaoui, A. (2009). The Role of Judicial Oversight in Protecting Rights and Freedoms in the Context of International Legislations and Agreements. Cairo: National Centre for Legal Issues.

El-Sharkawi, S. (2010). Egyptian Constitutional Law and Political System. Cairo: Arab Renaissance House. 
Hamad, A. M. (2019). End of the Minister's Legal Status in Palestinian Law. Hang Tuah Law Journal, 3(1), 60. https://doi.org/10.30649/htlj.v3i1.104

Hamad, A. M. A., Anuar, H. binti M., \& Halim, R. binti. (2020). the Presidential Powers of The Palestinian Minister within his Ministry. Journal of Human Rights, Culture, and Legal System, 1(1), 1-15.

Ma'rifatulloh, K. M. (2019). Ratio Legis Of The Constitutional Court Decision About Impeachment: Is It Final And Binding? Legality Jurnal Ilmiah Hukum, 27(2), 177. https://doi.org/10.22219/jihl.v27i2.10155

Metwally, A.-H. (1999). Constitutional Law and Political Systems with Comparison with Constitutional Principles in Islamic Sharia. Alexandria, Cairo: Maarif Institution.

Shitor, J. (2020). Judicial Control of the Constitutionality of Laws. Journal of Jurisprudence, 1(4), 65. https://doi.org/10.2307/837738

Stutz, C., \& Sachs, S. (2016). Facing the Normative Challenges: The Potential of Reflexive Historical Research. Sage Journals, 5(2), 32. https://doi.org/10.1177/0007650316681989

The Palestinian Basic Law. , (2003).

The ruling of the Supreme Court in its constitutional capacity held in Ramallah in Constitutional Law No. 1 of 2010. (2010). Retrieved July 8, 2020, from Mawsueat Almuqtafi Al'iliktrunia website: http://muqtafi.birzeit.edu/welcome.aspx

The ruling of the Supreme Court in its constitutional capacity held in Ramallah in Constitutional Law No. 640 of 2010. (2012). Retrieved July 8, 2020, from Mawsueat Almuqtafi Al'iiliktrunia website: http://muqtafi.birzeit.edu/welcome.aspx

The ruling of the Supreme Court in its constitutional capacity that was held in Ramallah in the constitutional case No. 3 of 2009. (2010). Retrieved July 8, 2020, from Mawsueat Almuqtafi Al'iliktrunia website: http://muqtafi.birzeit.edu/welcome.aspx

The ruling Supreme Court in its constitutional capacity held in Ramallah in Constitutional Law No. 2 of 2011. (2011). Retrieved July 8, 2020, from Mawsueat Almuqtafi Al'iiliktrunia website: http://muqtafi.birzeit.edu/welcome.aspx

The Supreme Constitutional Court Law. , Pub. L. No. 3 (2006). 